

\section{KEDUDUKAN DAN FUNGSI REKOMENDASI DPRD DALAM PENYELENGGARAAN KEWENANGAN PERIZINAN}

DADANG, S.H., M.H.

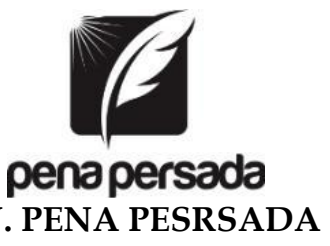




\section{KEDUDUKAN DAN FUNGSI REKOMENDASI DPRD DALAM PENYELENGGARAAN KEWENANGAN PERIZINAN}

\section{Penulis :}

Dadang , S.H., M.H.

\section{Editor:}

Wiwit Kurniawan

ISBN :978-623-6688-95-3

\section{Design Cover :}

Retnani Nur Briliant

\section{Layout :}

Hasnah Aulia

Penerbit CV. Pena Persada

\section{Redaksi :}

Jl. Gerilya No. 292 Purwokerto Selatan, Kab. Banyumas Jawa Tengah

Email : penerbit.penapersada@gmail.com

Website : penapersada.com

Phone : (0281) 7771388

Anggota IKAPI

All right reserved

Cetakan pertama : 2020

Hak cipta dilindungi oleh undang-undang.

Dilarang memperbanyak karya tulis ini dalam bentuk dan cara apapun tanpa ijin penerbit 


\section{KATA PENGANTAR}

Segala puji dan syukur hanyalah layak untuk Allah SWT. Dialah yang mengutus RasulNya dengan membawa petunjuk dan agama yang hak agar dimenangkanNya terhadap semua agama. Dan cukuplah Allah sebagai saksi. Sholawat dan salam penulis haturkan pada Rasulullah, manusia terbaik yang menjadi tauladan bagi kita semua, manusia yang senantiasa mengajarkan dan memberikan pembelajaran bagaimana kita menjadi seorang yang berarti dan bernilai di sisi Allah.

Besar harapan Penulis semoga buku ini dapat memberikan manfaat bagi para pembaca dan ilmu pengetahuan, terutama bagi Penulis sendiri, walaupun Penulis sadari bahwa buku ini masih jauh dari sempurna. Dalam penyusunan buku ini penulis mendapatkan banyak masukan, saran, dorongan dan juga bantuan dari semua pihak.

Dalam buku ini akan membahas kedudukan hukum dan fungsi DPRD dalam penyelenggaraan perizinan oleh Pemerintah Daerah Ditinjau dari Undang Undang Nomor 9 TAHUN 2015 tentang Pemerintahan Daerah dan Undang-Undang Nomor 30 Tahun 2014 Tentang Administrasi Pemerintahan, mengetahui kendala-kendala dalam penyelenggaraan perizinan oleh Pemerintah Daerah tanpa adanya rekomendasi dari DPRD. Rekomendasi DPRD pada Pemda provinsi tidak dikenal di dalam peraturan perundang-undangan yang mengatur tentang penyelenggaraan pemerintahan Negara dan peraturan perundangundangan teknis lainnya. Rekomendasi DPRD dalam penyelenggaraan pemerintahan daerah juga bukan merupakan penjabaran dawi kewenangan pengawasan DPRD terhadap gubernur. Rekomendasi yang dikenal di dalam peraturan perundang-undangan adalah rekomendasi sebagai instrumen hukum administrasi dalam penyelenggaraan pemerintahan oleh gubernur, khusunya dalam penyelenggaraan fungsi penetapan keputusan atau pelaksanaan tindak pemerintahan.

Mengingat kemampuan dan pengetahuan dari Penulis yang masih terbatas, Penulis menyadari bahwa dalam penyusunan. Bu- 
$\mathrm{ku}$ ini masih terdapat banyak kekurangan dan ketidak sempurnaan yang ditemui. Akhirnya penulis menyadari bahwa sebagai manusia biasa yang memiliki segala keterbatasan, dalam penyusunan buku ini masih terdapat kekurangan baik materi maupun teknis penyusunannya, oleh karena itu koreksi dan saran sangat penulis harapkan

Penulis

Dadang 


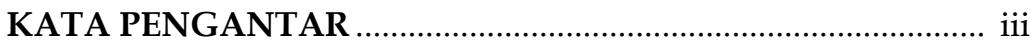

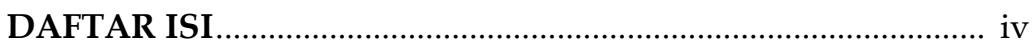

BAB I PENDAHULUAN

A. Penyelenggaraan Otonomi Daerah ..................................... 1

B. Penyelenggaraan Kewenangan Perizinan ............................. 2

BAB II KONSEP PEMERINTAH DAERAH DALAM PEMBERIAN IZIN

A. Pengertian dan Konsep Pemerintahan Daerah..................... 8

B. Pengertian dan Konsep Kewenangan ..................................... 14

C. Pengertian dan Konsep Izin dan Perizinan ........................... 18

D. Pengertian dan Konsep Rekomendasi ............................... 27

BAB III KEDUDUKAN DAN FUNGSI DPRD DALAM PENYELENGGARAAN PERIZINAN

A. Kedudukan dan Fungsi DPRD dalam Penyelenggaraan Pemerintahan Daerah......................................................... 34

B. Kedudukan dan Fungsi DPRD dalam Penerbitan Izin oleh Pemerintah Daerah....

\section{BAB IV REKOMENDASI DPRD DALAM} PENYELENGGARAAN PERIZINAN

A. Kedudukan dan Fungsi Rekomendasi DPRD dalam Penerbitan Izin 66

B. Implikasi Rekomendasi DPRD Terhadap Tanggungjawab DPRD dalam Penerbitan Izin 77

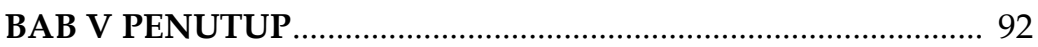

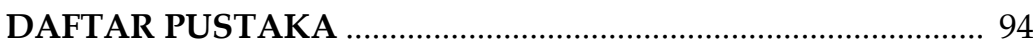


KEDUDUKAN DAN FUNGSI REKOMENDASI DPRD DALAM PENYELENGGARAAN KEWENANGAN PERIZINAN 


\section{BAB I \\ PENDAHULUAN}

\section{A. Penyelenggaraan Otonomi Daerah}

Pemerintah daerah, sesuai dengan amanat Undang Undang Dasar Negara Republik Indonesia Tahun 1945 (UUD 1945) berwenang untuk mengatur dan mengurus sendiri urusan pemerintahan berdasarkan asas otonomi dan tugas pembantuan. Pemberian otonomi luas kepada daerah bertujuan untuk mempercepat terwujudnya kesejahteraan masyarakat melalui peningkatan pelayanan, pemberdayaan, dan peran serta masyarakat. Pemerintahan Daerah (Pemda) dalam rangka meningkatkan efisiensi dan efektifitas penyelenggaraan otonomi daerah, perlu memperhatikan hubungan antar susunan pemerintahan.

Hubungan antar susunan pemerintahan mencakup aspek hubungan wewenang yang disusun berdasarkan kekhususan dan keragaman daerah dalam sistem Negara Kesatuan Republik Indonesia. Daerah diberikan kewenangan yang seluas-luasnya disertai dengan hak dan kewajiban menyelenggarakan otonomi daerah dalam satu kesatuan sistem penyelenggaraan pemerintahan negara. Prinsip otonomi daerah menggunakan prinsip otonomi seluas-luasnya mengandung pengertian daerah diberikan kewenangan mengurus dan mengatur semua urusan pemerintahan diluar yang menjadi urusan Pemerintah yang ditetapkan dalam undang-undang. Daerah memiliki kewenangan membuat kebijakan daerah untuk memberi pelayanan, peningkatan peran serta, prakarsa dan pemberdayaan masyarakat yang bertujuan untuk meningkatkan kesejahteraan rakyat.

Kata Pemerintahan dan kata Pemerintah memiliki pengertian yang berbeda. Pemerintah mengandung pengertian sebagai "organ" atau alat Negara yang menjalankan tugas dan fungsi pemerintahan, sedangkan pemerintahan mengandung 
pengertian sebagai "fungsi" dari pemerintah. Istilah Pemerintah dalam arti "organ" atau alat negara, dapat dibedakan menjadi dua yakni: Pemerintah dalam arti sempit, khusus hanya menyangkut kekuasaan eksekutif. Menurut UUD 1945, Pemerintah ialah Presiden, Wakil Presiden dan dibantu oleh menteri-menteri. Pemerintah dalam arti luas adalah semua organ Negara termasuk DPR (eksekutif dan legislatif ). ${ }^{1}$

Pemda adalah pelaksanaan fungsi-fungsi pemerintahan daerah yang dilakukan oleh lembaga pemerintahan daerah, yaitu Pemda dan DPRD. Gubernur sebagai kepala daerah provinsi berfungsi pula sebagai wakil pemerintah di daerah dalam pengertian untuk menjembatani dan memperpendek rentang kendali, pelaksanaan tugas dan fungsi pemerintah termasuk dalam pembinaan dan pengawasan terhadap penyelenggaraan urusan pemerintahan pada strata pemerintahan kabupaten dan kota

Hubungan antara Pemda dan DPRD merupakan hubungan kerja yang kedudukannya setara dan bersifat kemitraan. Kedudukan yang setara bermakna bahwa diantara lembaga pemerintahan daerah itu memiliki kedudukan yang sama dan sejajar, artinya tidak saling membawahi. Hal tersebut tercermin dalam membuat kebijakan daerah berupa Peraturan Daerah (Perda). Hubungan kemitraan memiliki makna, bahwa antara Pemerintah Daerah dan DPRD adalah sama-sama mitra kerja dalam membuat kebijakan daerah untuk melaksanakan otonomi daerah sesuai dengan tugas dan fungsi masing-masing sehingga antar kedua lembaga tersebut membangun suatu hubungan kerja yang sifatnya saling mendukung.

\section{B. Penyelenggaraan Kewenangan Perizinan}

Salah satu kewenangan yang dimiliki oleh pemerintah atau Pemda adalah kewenangan yang berkaitan dengan perizinan. Perizinan merupakan instrumen kebijakan pemerintah atau pemerintah daerah untuk melakukan pengendalian

${ }^{1}$ CST Kansil, Christine ST Kansil, J.Hanny Posumah,Said Aneke Rukiah, Hukum Administrasi Daerah, Jala Permata Aksara, Jakarta, 2009, hal. 87 
atas eksternalitas negatif yang mungkin ditimbulkan oleh aktivitas sosial maupun aktivitas ekonomi. Izin juga merupakan instrumen untuk perlindungan hukum atas kepemilikan atau penyelenggaraan kegiatan. Sebagai instrumen pengendalian, perizinan memerlukan rasionalitas yang jelas, yang tertuang dalam bentuk kebijakan pemerintah sebagai sebuah acuan. Tanpa rasionalitas dan desain kebijakan yang jelas, perizinan akan kehilangan maknanya sebagai instrumen untuk membela kepentingan masyarakat, kepentingan pelaku ekonomi atas tindakan yang berdasarkan kepentingan individu. Dengan demikian, fungsi perizinan adalah fungsi regulasi yang berada pada badan dan dilaksanakan oleh pemerintah. $^{2}$

Izin merupakan keputusan administratif yang lazim disebut dengan keputusan tata usaha negara. Keputusan tata usaha negara yang bernama izin tersebut, berisi pengaturan mengenai kegiatan yang dapat atau yang tidak dapat dilakukan oleh masyarakat. Izin adalah keputusan tata usaha negara yang dikeluarkan oleh pejabat yang berwenang dalam pemerintahan sebagai konsekuensi dari jabatannya.

Salah satu fungsi utama dari pemerintah adalah membuat kebijakan publik. Argumentasi terpenting dari pernyataan tersebut adalah bahwa semua warganegara akan senantiasa bersentuhan dengan kebijakan publik yang dikeluarkan oleh pemerintah, karena yang diatur oleh kebijakan publik tentunya yang menyangkut kepentingan umum. ${ }^{3}$ Pernyataan tersebut memberikan gambaran tentang fungsi pemerintahan yang berlaku secara umum, dalam arti tugas pemerintahan yang berjalan sebagaimana diatur hukum administrasi.

Dengan demikian, secara gambaran umum memperlihatkan bahwa fungsi pemerintahan adalah menjalankan semua kegiatan diluar fungsi legislatif dan

${ }^{2}$ Andrian Sutedi, Hukum Perizinan dalam sektor pelayanan publik, Sinar Grafika, Jakarta, 2011, hal.v

${ }^{3}$ Muhadam Labolo, Memahami Ilmu Pemerintahan, PT. Radja Grafindo Persada, Jakarta, 2006, hal.27 
yudikatif atas dasar ketentuan dan kewenangan yang diberikan. Fungsi Administrasi (pemerintahan) sebagai fungsi hukum terdiri atas:

1. Pengaturan administrasi, penetapan peraturan-peraturan administasi berupa peraturan pemerintah, peraturan presiden, peraturan menteri, dan sebagainya yang bersifat administratif, artinya berupa interprestasi penjabaran, petunjuk atau instruksi pelaksanaan undang-undang;

2. Tata pemerintahan, penggunaan kekuasaan yuridis formal negara terhadap orang-orang penduduk negara dan segala apa yang terdapat dalam wilayah negara di dalam menegakkan pemerintahan Negara secara nyata. Penggunaan kekuasaan ini adalah untuk menjalankan dan mencapai secara yuridis, segala apa yang menjadi fungsi, tugas, kewajiban atau tujuan daripada negara dalam mengurus kehidupan masyarakat;

3. Kepolisian administrasi, penegakan hukum secara langsung, yakni pengawasan dan pemeliharaan ketertiban serta keamanan terhadap pelaksanaan hukum yang bersifat pembinaan dan pendidikan masyarakat;

4. Penyelesaian perselisihan secara administratif, yakni penyelesaian perkara-perkara atau persengketaansengketaan yang dapat diselesaikan oleh pengadilan yustisi, yaitu perkara-perkara "administrasi". ${ }^{4}$

Dalam menjalankan fungsi pemerintahan berdasarkan ketentuan hukum atau perundang-undangan, maka harus berdasarkan kewenangan yang diberikan atau diterima melalui ketentuan hukum yang berlaku. Wewenang mengandung arti kemampuan untuk melakukan suatu tindakan hukum publik, atau secara yuridis adalah kemampuan bertindak yang diberikan oleh undang-undang yang berlaku untuk melakukan hubungan hukum. Dengan demikian wewenang pemerintahan memiliki sifat-sifat, antara

4 S.Prajudi Atmosudirdjo, Hukum Administrasi Negara, Edisi revisi, Gahlia Indonesia, Cetakan ke -10, Jakarta, 1994, hal.73-74 
lain:

1. Express Implied;

2. Jelas maksud dan tujuannya;

3. Terikat pada waktu tertentu;

4. Tunduk pada batasan-batasan hukum tertulis dan tidak tertulis;

5. Isi dan wewenang dapat bersifat umum (abstrak) dan kongkrit. ${ }^{5}$

Berkenaan dengan kewenangan untuk melaksanakan tindakan hukum publik ini, maka perlu untuk melihat dan mengamati penyelenggaraan kewenangan pemerintah daerah di dalam menjalankan fungsi pemerintahan, khususnya kewenangan bidang perizinan. Kewenangan Pemda dalam bidang perizinan secara eksplisit tidak ditemukan dalam undang-undang, baik Undang-Undang Pemerintahan Daerah, Undang-Undang Administrasi Pemerintahan, maupun Undang-Undang Pelayanan Publik. Namun demikian, pemerintah daerah memiliki kewenangan tersebut, yang secara implisit dapat ditemukan pada Pasal 1 ayat (5), Pasal 20, Pasal 21, Pasal 22, dan Pasal 25 Undang Undang Nomor 9 TAHUN 2015 tentang Pemerintahan Daerah (UUPemda). Kewenangan yang sama secara implisit juga terkandung di dalam Undang-Undang Nomor 30 Tahun 2014 Tentang Administrasi Pemerintahan (selanjutnya: UUAP). Pasal 39 ayat (1) UUAP menentukan bahwa Pejabat Pemerintahan yang berwenang dapat menerbitkan Izin, Dispensasi, dan/atau Konsesi dengan berpedoman pada AUPB dan berdasarkan ketentuan peraturan perundang-undangan. Namun demikian, pengaturan teknis mengenai kewenangan Pemda dalam bidang perizinan secara eksplisit baru ditemukan dalam Peraturan Presiden Republik Indonesia Nomor 97 Tahun 2014 Tentang Penyelenggaraan Pelayanan Terpadu Satu Pintu (selanjutnya: Perpres PTSP). Pasal 5 ayat (1) huruf a dan c Perpres PTSP

5 SF Marbun, Peradilan Administrasi Negara dan Upaya Administratif di Indonesia, Liberty, Yogyakarta, 1997, hal.154-155 
menentukan bahwa penyelenggaraan PTSP dilaksanakan oleh pemerintah provinsi untuk pelayanan Perizinan dan Nonperizinan dari urusan wajib dan urusan pilihan yang menjadi urusan provinsi dan pemerintah kabupaten/kota untuk pelayanan Perizinan dan Nonperizinan dari urusan wajib dan urusan pilihan yang menjadi urusan kabupaten/kota.

Kewenangan pemerintahan dalam bidang perizinan merupakan kewenangan dan tindakan pemerintahan yang berhubungan dengan kepentingan umum, bahkan dalam sifat yang langsung. Perhatian secara lebih baik terhadap kewenangan ini sangat diperlukan dalam kaitan dengan perlindungan kepentingan publik, mengingat aktor kewenangan itu adalah manusia yang sepanjang sejarah manusia terbukti tidak selamanya dan sepenuhnya menggunakan komitmen jabatannya untuk melaksanakan fungsi jabatan sesuai dengan kaedah peraturang perundangundangan yang mengatur kewenangan itu. Berbagai kasus dalam bentuk penyalahgunaan wewenang dalam penyelenggaraan kewenangan perizinan yang mengancam kepentingan publik merupakan sisi lain dari fakta penyelenggaraan kewenangan pemerintahan dalam bidang perizinan yang membuat bidang ini layak diberikan perhatian lebih dalam rangka mencegah berbagai kerugian yang dapat terjadi sebagai akibat dari penyelenggaraan kewenangan demikian itu. Perhatian ini juga diperlukan dalam kaitan dengan sifat dari kelembagaan lembaga perizinan itu sebagai suatu lembaga hukum yang yang tidak berdiri sendiri, melainkan sebagai bagian dari satu sistem kekuasaan dan kewenangan dalam sistem pemerintahan yang mengakibatkan kelembagaan lembaga perizinan itu terbangun dalam suatu struktur sistem kelembagaan yang berkorelasi dengan berbagai lembaga pemerintahan di luar eksekutif.

Uraian tentang fakta penyelenggaraan kewenangan perizinan oleh Pemda tersebut, membuktikan adanya kendali kewenangan oleh DPRD terhadap penyelenggaraan fungsi 
perizinan oleh Pemda. DPRD sebagai salah satu bentuk perwakilan rakyat di tingkat provinsi sebagaimana diatur dalam Pasal 371 Undang-Undang Nomor 17 Tahun 2014 tentang Majelis Permusyawaratan Rakyat, Dewan Perwakilan Rakyat, Dewan Perwakilan Daerah, dan Dewan Perwakilan Rakyat Daerah memiliki tiga macam hak yaitu hak interpelasi, angket dan menyatakan pendapat. Perwujudan dari hak yang dimiliki oleh DPRD tersebut adalah dikeluarkannya Rekomendasi DPRD.

Berdasarkan fakta hukum yang ada, Rekomendasi DPRD merupakan wujud nyata dari adanya kendali kewenangan oleh DPRD dalam penyelenggaraan fungsi perizinan oleh Pemda, Rekomendasi ini dapat menimbulkan (dua) karakter sebagai bentuk respon Gubernur terhadap rekomendasi DPR tersebut, yakni karakter mengikat/mengikuti atau karakter tidak mengikat/tidak mengikuti.

Secara teori, perizinan memerlukan payung hukum berupa Perda dan/atau Peraturan Perundang-undangan lainnya. Sementara Gubernur memperoleh kewenangan penuh terhadap pemberian perizinan sebagai mana diatur dalam Peraturan Perundang-undangan dan Perda. Fungsi Rekomendasi DPRD menjadi kabur atau tidak jelas dikaitkan dengan kewenangan Pemerintah Daerah dalam pengeluaran perizinan. Gubernur dapat mengeluarkan izin tanpa perlu adanya rekomendasi dari DPRD. Sehingga kedudukan dan fungsi rekomendasi hanya menjadi pelengkap untuk dikeluarkannya perizinan. Dalam praktek, lembaga rekomendasi DPRD merupakan lembaga yang digunakan secara luas. Karena itu, keberadaan rekomendasi DPRD perlu disikapi secara sistematik untuk mencegah akibat buruk dari penggunaannya. 


\section{BAB II \\ KONSEP PEMERINTAH DAERAH DALAM PEMBERIAN IZIN}

\section{A. Pengertian dan Konsep Pemerintahan Daerah}

Pemerintahan memiliki dua arti, yakni dalam arti luas dan dalam arti sempit. Pemerintahan dalam arti luas yang disebut regering atau goverment, yakni pelaksanaan tugas seluruh badan-badan, lembaga-lembaga dan petugas-petugas yang diserahi wewenang mencapai tujuan negara. Arti pemerintahan meliputi kekuasaan legislatif, eksekutif, dan yudikatif atau alat-alat kelengkapan negara yang lain yang juga bertindak untuk dan atas nama negara. Sedangkan pemerintah dalam arti sempit (bestuurvoering), yakni mencakup organisasi fungsi-fungsi yang menjalankan tugas pemerintahan. Titik berat pemerintahan dalam arti sempit ini hanya berkaitan dengan kekuasaan yang menjalankan fungsi eksekutif saja. ${ }^{6}$

Philipus M. Hadjon memberikan pendapatnya mengenai Pemerintahan sebagai berikut: Pemerintahan dapat dipahami melalui dua pengertian: di satu pihak dalam arti "fungsi pemerintahan" (kegiatan memerintah), di lain pihak dalam arti "organisasi pemerintahan" (kumpulan dari kesatuan-kesatuan pemerintahan). Fungsi pemerintahan ini secara keseluruhan terdiri dari berbagai macam tindakan-tindakan pemerintahan: keputusan-keputusan, ketetapan-ketetapan yang bersifat umum, tindakan-tindakan hukum perdata dan tindakantindakan nyata. Hanya perundang-undangan dari penguasa politik dan peradilan oleh para hakim tidak termasuk di dalamnya. ${ }^{7}$

Menurut Suhady, pemerintah (government) ditinjau dari pengertiannya adalah the authoritative direction and adminis-

${ }^{6}$ Sadjijono, Memahami Beberapa Bab Pokok Hukum Administrasi, Laksbang Pressindo, Yogjakarta, 2008, hal. 41

7 Philipus M. Hadjon, dkk., Pengantar Hukum Administrasi Indonesia (Introduction to the Indonesian Administrative Law) Gajahmada University Press, Yogjakarta, Cet. Kesembilan, 2005, hal. 6-8 
tration of the affairs of men/women in a nation state, city, ect. Dalam bahasa Indonesia sebagai pengarahan dan administrasi yang berwenang atas kegiatan masyarakat dalam sebuah Negara, kota dan sebagainya. Pemerintahan dapat juga diartikan sebagai the governing body of a nation, state, city, etc yaitu lembaga atau badan yang menyelenggarakan pemerintahan Negara, Negara bagian, atau kota dan sebagainya. ${ }^{8}$

Dengan demikian lahirnya pemerintahan memberikan pemahaman bahwa kehadiran suatu pemerintahan merupakan manifestasi dari kehendak masyarakat yang bertujuan untuk berbuat baik bagi kepentingan masyarakat. Defenisi ini menggambarkan bahwa pemerintahan sebagai suatu ilmu mencakup 2 (dua) unsur utama yaitu: pertama, masalah bagaimana sebaiknya pelayanan umum dikelola, jadi termasuk seluruh permasalahan pelayanan umum, dilihat dan dimengerti dari sudut kemanusiaan; kedua, masalah bagaimana sebaiknya memimpin pelayanan umum, jadi tidak hanya mencakup masalah pendekatan yaitu bagaimana sebaiknya mendekati masyarakat oleh para pengurus, dengan pendekatan terbaik, masalah hubungan antara birokrasi dengan masyarakat, masalah keterbukaan juga keterbukaan yang aktif dalam hubungan masyarakat, permasalahan psikologi sosial dan sebagainya.

Reformasi pemerintahan yang terjadi di Indonesia, saat ini telah mengakibatkan pula terjadinya pergeseran paradigma dari sentralistik ke arah desentralisasi, yang ditandai dengan pemberian otonomi kepada daerah. Pengalaman dari banyak negara mengungkapkan bahwa pemberian otonomi kepada daerah-daerah merupakan salah satu resep politik penting untuk mencapai sebuah stabilitas sistem dan sekaligus membuka kemungkinan bagi proses demokratisasi yang pada gilirannya nanti akan semakin mengukuhkan stabilitas sistem secara keseluruhan. Pelaksanaan desentralisasi dengan pemberian otonomi kepada daerah tidak demikian mudahnya

\footnotetext{
${ }^{8}$ Riawan, 2009, Hukum Pemerintahan Daerah, Citra Aditya Bakti, Bandung, hal.
} 
memenuhi keinginan daerah bahwa dengan otonomi daerah segalanya akan berjalan lancar dan mulus. Keberhasilan otonomi daerah sangat bergantung pada pemerintah daerah dalam hal ini adalah DPRD dan Kepala Daerah, serta Perangkat Daerah lainnya. Dengan demikian, perlu adanya hubungan yang harmonis antara DPRD dan Kepala Daerah

Pembentukan pemerintahan daerah sesuai dengan amanat Pasal 18 UUD 1945 menjadi dasar dari berbagai produk undang-undang dan peraturan perundang-undangan lainnya yang mengatur mengenai pemerintah daerah. Tujuan pembentukan daerah pada dasarnya dimaksudkan untuk meningkatkan pelayanan publik guna mempercepat terwujudnya kesejahteraan masyarakat disamping sebagai sarana pendidikan politik di tingkat lokal.

Hubungan Pemerintah Pusat dengan Daerah dapat dirunut dari alinea ketiga dan keempat Pembukaan UUD 1945. Alinea ketiga memuat pernyataan kemerdekaan bangsa Indonesia. Sedangkan alinea keempat memuat pernyataan bahwa setelah menyatakan kemerdekaan, yang pertama kali dibentuk adalah Pemerintah Negara Indonesia yaitu Pemerintah Nasional yang bertanggung jawab mengatur dan mengurus bangsa Indonesia. Lebih lanjut dinyatakan bahwa tugas Pemerintah Negara Indonesia adalah melindungi seluruh bangsa dan tumpah darah Indonesia, memajukan kesejahteraan umum dan mencerdaskan kehidupan bangsa serta ikut memelihara ketertiban dunia berdasarkan kemerdekaan, perdamaian abadi, dan keadilan sosial. Selanjutnya Pasal 1 UUD 1945 menyatakan bahwa "Negara Indonesia adalah negara kesatuan yang berbentuk republik." Konsekuensi logis sebagai Negara kesatuan adalah dibentuknya pemerintah Negara Indonesia sebagai pemerintah nasional untuk pertama kalinya dan kemudian pemerintah nasional tersebutlah yang kemudian membentuk Daerah sesuai ketentuan peraturan perundang-undangan. Kemudian Pasal 18 ayat (2) dan ayat (5) UUD 1945 menyatakan bahwa "Pemerintahan Daerah berwenang untuk mengatur dan mengurus sendiri Urusan 
Pemerintahan menurut Asas Otonomi dan Tugas Pembantuan dan diberikan otonomi yang seluas-luasnya."

Pemberian otonomi yang seluas-luasnya kepada Daerah diarahkan untuk mempercepat terwujudnya kesejahteraan masyarakat melalui peningkatan pelayanan, pemberdayaan, dan peran serta masyarakat. Di samping itu melalui otonomi luas, dalam lingkungan strategis gloDKI Jakartasasi, Daerah diharapkan mampu meningkatkan daya saing dengan memperhatikan prinsip demokrasi, pemerataan, keadilan, keistimewaan dan kekhususan serta potensi dan keanekaragaman Daerah dalam sistem Negara Kesatuan Republik Indonesia.

Pemberian otonomi yang seluas-seluasnya kepada Daerah dilaksanakan berdasarkan prinsip negara kesatuan. Dalam negara kesatuan kedaulatan hanya ada pada pemerintahan negara atau pemerintahan nasional dan tidak ada kedaulatan pada Daerah. Oleh karena itu, seluas apa pun otonomi yang diberikan kepada Daerah, tanggung jawab akhir penyelenggaraan Pemerintahan Daerah akan tetap ada ditangan Pemerintah Pusat. Untuk itu Pemerintahan Daerah pada negara kesatuan merupakan satu kesatuan dengan Pemerintahan Nasional. Sejalan dengan itu, kebijakan yang dibuat dan dilaksanakan oleh Daerah merupakan bagian integral dari kebijakan nasional.

Pembedanya adalah terletak pada bagaimana memanfaatkan kearifan, potensi, inovasi, daya saing, dan kreativitas Daerah untuk mencapai tujuan nasional tersebut di tingkat lokal yang pada gilirannya akan mendukung pencapaian tujuan nasional secara keseluruhan.

Daerah otonom sebagai satuan yang pemerintahan yang mandiri yang memiliki wewenag atributif, terlebih lagi sebagai subjek hukum (publick rechtpersoon publick legal entity) berwenang membuat peraturan-peraturan untuk menyelenggarakan rumah tangganya. Wewenang ini mengatur ini ada pemerintah daerah (pejabat administrasi daerah) dan 
DPRD sebagai pemegang fungsi legislasi di daerah. ${ }^{9}$

Pada hakikatnya Otonomi Daerah diberikan kepada rakyat sebagai satu kesatuan masyarakat hukum yang diberi kewenangan untuk mengatur dan mengurus sendiri Urusan Pemerintahan yang diberikan oleh Pemerintah Pusat kepada Daerah dan dalam pelaksanaannya dilakukan oleh kepala daerah dan DPRD dengan dibantu oleh Perangkat Daerah. Urusan Pemerintahan yang diserahkan ke Daerah berasal dari kekuasaan pemerintahan yang ada ditangan Presiden. Konsekuensi dari negara kesatuan adalah tanggung jawab akhir pemerintahan ada ditangan Presiden. Agar pelaksanaan Urusan Pemerintahan yang diserahkan ke Daerah berjalan sesuai dengan kebijakan nasional maka Presiden berkewajiban untuk melakukan pembinaan dan pengawasan terhadap penyelenggaraan Pemerintahan Daerah.

Lahirnya pemerintahan pada awalnya adalah untuk menjaga suatu sistem ketertiban di dalam masyasrakat, sehingga masyarakat tersebut bisa menjalankan kehidupan secara wajar. Seiring dengan perkembangan masyarakat modern yang ditandai dengan meningkatnya kebutuhan, peran pemerintah kemudian berubah menjadi melayani masyarakat. Pemerintah modern, dengan kata lain pada hakekatnya adalah pelayanan kepada masyarakat. Pemerintah tidaklah diadakan untuk melayani diri sendiri, tetapi untuk melayani masyarakat, menciptakan kondisi yang memungkinkan setiap anggota mengembangkan kemampuan dan kreatifitasnya demi mencapai kemajuan bersama.

Penyelenggaraan pemerintahan daerah diarahkan untuk mempercepat terwujudnya kesejahteraan masyarakat melalui peningkatan pelayanan, pemberdayaan, dan peran serta masyarakat, serta peningkatan daya saing daerah dengan memperhatikan prinsip demokrasi, pemerataan, keadilan, dan kekhasan suatu daerah dalam sistem Negara Kesatuan Republik Indonesia. efisiensi dan efektivitas penyelenggaraan

9 Bagir Manan, Menyongsong Fajar Otonomi Daerah, Pusat Studi Hukum FHUI, Jakarta, 2000, hal. 70 
pemerintahan daerah perlu ditingkatkan dengan lebih memperhatikan aspek-aspek hubungan antara Pemerintah Pusat dengan daerah dan anta rdaerah, potensi dan keanekaragaman daerah, serta peluang dan tantangan persaingan global dalam kesatuan sistem penyelenggaraan pemerintahan negara. Undang-Undang Nomor 32 Tahun 2004 tentang Pemerintahan Daerah tidak sesuai lagi dengan perkembangan keadaan, ketatanegaraan, dan tuntutan penyelenggaraan pemerintahan daerah sehingga perlu diganti, oleh karena itu pemerintah kemudian menetapkan UndangUndang Republik Indonesia Nomor 23 Tahun 2014 tentang Pemerintahan Daerah.

Menurut ketentuan yang diatur dalam Pasal 1 angka 3 UU Pemda menyatakan bahwa: "Pemerintah Daerah adalah kepala daerah sebagai unsur penyelenggara Pemerintahan Daerah yang memimpin pelaksanaan urusan pemerintahan yang menjadi kewenangan daerah otonom." Kemudian dalam Pasal 1 angka 4 UU Pemda menyatakan bahwa: "DPRD adalah lembaga perwakilan rakyat daerah yang berkedudukan sebagai unsur penyelenggara Pemerintahan Daerah."

Berbeda dengan penyelenggaraan pemerintahan di pusat yang terdiri atas lembaga eksekutif, legislatif, dan yudikatif, penyelenggaraan Pemerintahan Daerah dilaksanakan oleh DPRD dan kepala daerah. DPRD dan kepala daerah berkedudukan sebagai unsur penyelenggara pemerintahan daerah yang diberi mandat rakyat untuk melaksanakan Urusan Pemerintahan yang diserahkan kepada Daerah. Dengan demikian maka DPRD dan kepala daerah berkedudukan sebagai mitra sejajar yang mempunyai fungsi yang berbeda. DPRD mempunyai fungsi pembentukan Perda, anggaran dan pengawasan, sedangkan kepala daerah melaksanakan fungsi pelaksanaan atas Perda dan kebijakan Daerah. Dalam mengatur dan mengurus Urusan Pemerintahan yang menjadi kewenangan Daerah tersebut, DPRD dan kepala daerah dibantu oleh Perangkat Daerah. Sebagai konsekuensi posisi DPRD sebagai unsur penyelenggara Pemerintahan Daerah 